\title{
Efficacy of Citrus reticulata and Mirazid in treatment of Schistosoma mansoni
}

\author{
Manal A Hamed/ ${ }^{+}$, Mona H Hetta*
}

Departments of Medicinal Chemistry *Chemistry of Natural Compounds, National Research Centre, Dokki, Cairo, Egypt

This work has been carried out to investigate the effect of Schistosoma mansoni infection on mice livers after treatment with the ethanolic extract of Citrus reticulata root or the oleo-resin extract from Myrrh of Commiphora molmol tree (Mirazid), as a new antishistosomal drug. Marker enzymes for different cell organelles were measured; succinate dehydrogenase (SDH); lactate dehydrogenase $(L D H)$ and its isoenzymes; glucose-6-phosphatase (G-6Pase); acid phosphatase (AP) and 5'- nucleotidase. Liver function enzymes; aspartate aminotransferase (AST); alanine aminotransferase (ALT), and alkaline phosphatase (ALP) were also estimated. Parasitological studies through ova count and worm burden will also be taken into consideration. The results showed a marked reduction in SDH, LDH, AST, and ALT enzyme activities and a significant increase in G-6-Pase, AP, 5'-nucleotidase, and ALP after $\mathrm{S}$. mansoni infection. A noticeable alteration in $\mathrm{LDH}$ subunits were also noticed. Treatment with $\mathrm{C}$. reticulata or Mirazid improved all the previous enzyme activities with a noticeable reduction in ova count and worm burden.

Key words: Citrus reticulata - Mirazid - schistosomiasis - enzymes, worm burden - ova count

Schistosomiasis, a chronic and debilitating parasitic disease, affects approximately 200 million people in the developing world and imposes a substantial public health and economic impact, despite the continuous control efforts (Wang et al. 2004).

Current control of the disease by chemotherapeutic agents is impractical because of the common occurrence of re-infection after treatment due to the relative resistance of the larval stages of Schistosoma mansoni to schistosomicide drugs (Silva et al. 2003). Praziquantel, the currently used drug for chemotherapeutic control, was reported to induce hemorrhage in the lung tissue of the host (Flisser \& McLaren 1989) as well as abdominal pain and diarrhea (Kabatereine et al. 2003). The new trends nowadays is the use of natural plant extracts as new safe and effective drugs.

In this study, Citrus reticulata root extract and Myrrh from Commiphora molmol tree (Mirazid) are evaluated for their antischistosomal activity. Extract of $C$. reticulata roots has been reported as anticancer (Manthey \& Guthrie 2002), antibacterial (Tkachenko et al. 1999) as well as antioxidants activity (Hara et al. 2004). In addition, Withman et al. (2005) recorded the ability of citrus fruit-derived flavonoids to reduced plasma cholesterol concentration. Moreover, commiphora extract has been reported as a new safe and effective drug against $S$. mansoni and $S$. heamatobium (Abo-Madyan et al. 2004).

The present study is a trial to clarify the antischistosomal effect of $C$. reticulata root extract compared to commiphora extract (Mirazid). Enzyme markers for different cell organelles were measured in liver of S. mansoni

+Corresponding author. E-mail: manal_hamed@yahoo.com Received 7 June 2005

Accepted 28 September 2005 infected mice; succinate dehydrogenase (SDH) for mitochondria; lactate dehydrogenase (LDH), and its isoenzymes for cytoplasm; glucose-6-phosphatase (G-6-Pase) for microsomes; acid phosphatase (AP) for lysosomes and 5'- nucleotidase for plasma membrane. Liver function enzymes; aspartate aminotransferase (AST); alanine aminotransferase (ALT) and alkaline phosphatase (ALP) were also measured. Parasitological studies through ova count and worm burden will take into consideration.

\section{MATERIALS AND METHODS}

Chemicals - All chemicals used in the present study were of high analytical grade, products of Sigma (US), Merck (Germany), BDH (England).

Mirazid (the oleo-resin extract from Myrrh of $C$. molmol tree, family: Burseraceae) is a product of Pharco Pharmaceutical Company, Egypt.

Animals - The animals used were intact male Swiss albino mice of CDI strain of similar age (8 weeks) and weight (18-20 g). They were obtained from Theodor Bilharz Research Institute, Cairo, Egypt. Animals were kept in a controlled environment and were maintained on water and stock commercial pellet diet ad libitum.

Plant material - C. reticulata (Family: Rutaceae) roots were collected from Modereyet El Tahrir, Behera, Egypt. It was authenticated by Dr Mohamed Abdel Ghaffar, Faculty of Agriculture, Al- Azhar University, Egypt. A voucher specimen is deposited at Chemistry of Natural Compounds Dept., National Research Center, Dokki, Cairo, Egypt.

Extraction and isolation - Air dried powered roots of C. reticulata $(0.85 \mathrm{~kg})$ were extracted with $80 \%$ ethyl alcohol. The ethanolic extract was evaporated and the aqueous residue extracted sequentially thrice with equal volumes of n-hexane, ether, ethyl acetate, and n-butanol. The ethyl acetate extract was evaporated to dryness. The residue monitored by TLC using precoated silica gel 60 F254 aluminium sheets $(0.2 \mathrm{~mm}$ thickness, Merk), was found to 
contain flavonoids. The phenolic residue was subjected to biochemical determinations.

Doses and route of administration - Oral dose of 10 $\mu \mathrm{g} / \mathrm{ml} /$ mice of the phenolic extract of $C$. reticulata root was given daily for three consecutive weeks which the more effective dose as described by (Nogata et al. 2001).

Oral dose of Mirazid (600 mg/kg body weight) was given for three consecutive days on empty stomach, at least $1 \mathrm{~h}$ before meal regarding to the concentration of Mirazid illustrated in the brochure of the drug (Haridy et al. 2003).

Experimental design - The animals were divided into six groups each of eight mice. Group 1: normal healthy control. Group 2: received $C$. reticulata extract daily for three weeks, left one week and sacrificed. Group 3: received Mirazid daily for three days, left for 27 days and sacrificed. Group 4: S. mansoni infected mice with 100 cercariae of Egyptian strain with tail immersion technique (Oliver \& Stirewalt 1952) and sacrificed after two months. Group 5: received C. reticulata extract daily for three weeks post two months of $S$. mansoni infection. Mice left for one week after treatment and sacrificed. Group 6: received Mirazid daily for three days after two months of $S$. mansoni infection. Animals left for 27 days after treatment and sacrificed.

Preparation of tissue homogenates - Liver tissue was homogenized in $0.9 \mathrm{~N} \mathrm{NaCl}$ by a ratio $1: 10 \mathrm{w} / \mathrm{v}$ for estimation of all enzymes under investigation, while it was homogenized in $0.01 \mathrm{M}$ tris-glycine buffer by a ratio $1: 10 \mathrm{w} / \mathrm{v}$ for estimation of LDH isoenzymes, where $100 \mu \mathrm{g}$ protein was applied to each gel.

Parameter assays - Enzyme activities were evaluated using end point assay method. SHD: the reduction of FAD is coupled with a reduction of tetrazolium salt as INT, the produced formazan of INT is measured colorimetrically at $490 \mathrm{~nm}$ (Shelton \& Rice 1957). LDH: the reduction of NAD coupled with the reduction of tetrazolium salt with PMS serving as an intermediate election carrier, the resulted formazan of INT was measured colorimetrically at $503 \mathrm{~nm}$ (Babson \& Babson 1973). LDH isoenzymes (Dietz \& Lubrano 1967). The three enzymes, G-6-Pase, AP, and 5'nucleotidase were measured colorimetrically at $660 \mathrm{~nm}$ through measuring the inorganic phosphorus release (Swanson 1955, Wattiaux \& De Duve 1956, Bodansky \& Schwartz 1963, respectively). AST and ALT were estimated through measuring oxaloacetate and pyruvate produced respectively (Reitman \& Frankel 1957). ALP were measured as a liberated phenol in the presence of amino-4antipyrine and sod-arsenate as a blocking agent and potassium ferricyanide as a color reagent. The developed color measured at $510 \mathrm{~nm}$ (Kind \& King 1954). Total protein was estimated by the method of Bradford (1976) using Coomassie Blue Dye in the present of bovine serum albumin. The developed color was measured at $595 \mathrm{~nm}$.

Worm counting - Worms were recovered by liver perfusion as described by Smithers and Terry (1965). The percent of reduction in worm number after challenge was calculated by the method of Tendler et al. (1986) as follows :

$$
\mathrm{P}=\mathrm{C}-\mathrm{V} / \mathrm{C} \times 100
$$

where $\mathrm{P}=\%$ of protection, $\mathrm{C}=$ mean number of parasite recovered from infected animals and $\mathrm{V}=$ mean number of parasite recovered from treated animals.

Ova count - The number of ova/g tissue was counted by the method of Cheever and Anderson (1971), where

$$
\begin{aligned}
& \text { Number of ova } \\
& \text { in } 1 \mathrm{~g} \text { of liver }
\end{aligned}=\frac{\text { Number of ova in } 5 \mathrm{ml} \mathrm{KOH}}{\begin{array}{l}
\text { Weight of liver in grams recorded } \\
\text { before digestion in } \mathrm{KOH}
\end{array}}
$$

Statistical analysis - Data in the present study are presented as mean \pm S.D. Statistical significance values were determined by one way analysis of variance (ANOVA) accompanied by post-hoc (SPSS Computer Program).

\section{RESULTS}

Table I illustrates significant reduction of SDH and LDH, while significant increase in G-6- Pase, AP, and 5'nucleotidase enzyme activities of $S$. mansoni infected mice. Infected treated mice recorded amelioration levels after treatment with $C$. reticulata and Mirazid amounting 16.27 and $23.25 \%$ for SDH, 8.40 and $15.29 \%$ for $\mathrm{LDH}, 56.15$, and $60.91 \%$ for G-6- Pase, 12.82 and $17.94 \%$ for AP, 10.91 and $14.54 \%$ for 5'-nucleotidase, respectively. Normal healthy control mice received $C$. reticulata and Mirazid showed insignificant changes.

Table II and the Figure show significant variation in LDH subunits in S. mansoni infected mice. Treatment of infected mice with $C$. reticulata and Mirazid recorded improvement in $\mathrm{LDH}_{4}$ and $\mathrm{LDH}_{5}$, the subunits responsible for liver inflammation, by 74.10 and $75.02 \%$ for $\mathrm{LDH}_{4}$ and 14.66 and $14.84 \%$ for $\mathrm{LDH}_{5}$, respectively. Insignificant changes were recorded in $\mathrm{LDH}_{4}$ and $\mathrm{LDH}_{5}$ after treatment of healthy normal mice with both plant extracts.

Table III demonstrates significant reduction in AST and ALT, while a significant increase in ALP was recorded after bilharzial infection. S. mansoni infected mice treated with $C$. reticulata and Mirazid show enhancement levels amounting 25.93 and $29.56 \%$ for AST, $27.28,38.98 \%$ for ALT, and 20.16, 29.83\% for ALP, respectively. Healthy control mice administered with both extracts recorded insignificant change.

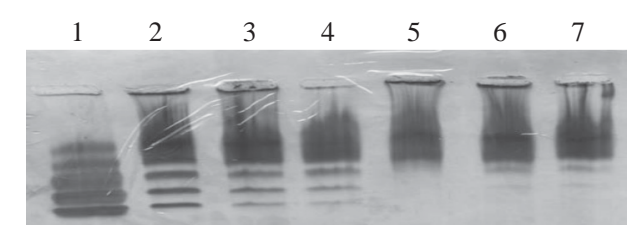

Electophoretic separation pattern of lactata dehydrogenase isoenzymes in mice liver. 1: hearth (standard); 2: control liver; 3: control treated with Citrus reticulata extract; 4: control treated with Mirazid; 5: infected; 6: infected treated with $C$. reticulata extract; 7: infected with Mirazid. 

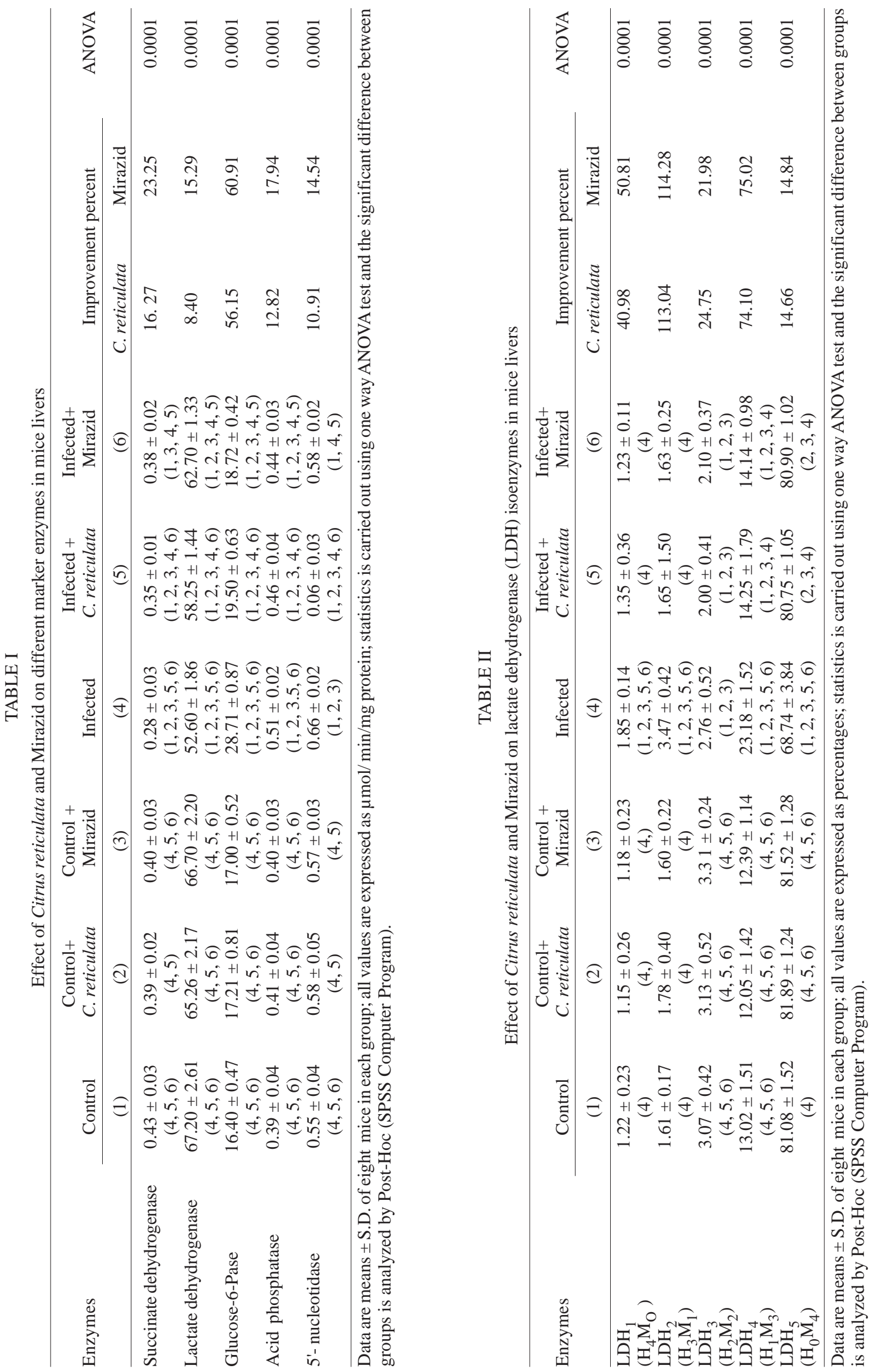


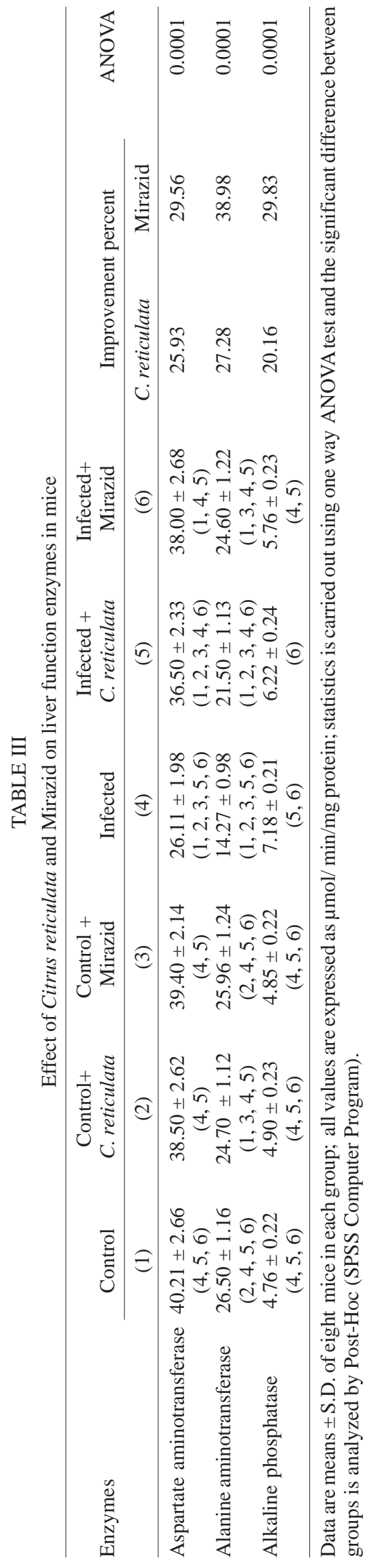

Table IV shows worm burden and ova count in $S$. mansoni infected mice treated with $C$. reticulata and Mirazid. Significant reduction in worm and ova count amounting 63.66 and $59.45 \%$ for $C$. reticulata and 81.10 and $73.07 \%$ for Mirazid, respectively.

\section{DISCUSSION}

The liver plays an important role in the vital activities of the body where its hepatocytes show differences in the localization and concentration of some enzyme systems (Gumucio \& Chiamale 1988). Many of these enzymes served as marker enzymes for different cell organelles and any defect of them will be reflected to the enzyme activity itself (Van Noorden \& Frederiks 1992). Hence, studying changes in these enzymatic activities could be helpful in evaluating the possible side effects of different treatments on different cell organelles after S. mansoni infection and the improvement occurring in such enzymes after treatment.

Concerning SDH enzyme activity, the present results revealed a significant decrease in its activity two months post infection. This is in agreement with Ismail et al. (1991). Daugherty (1955) attributed this failure to Schistosoma toxins which accumulated with the mitochondrial fraction and reflected on enzyme activity. SDH is the marker enzyme of the mitochondria (Van Noorden \& Frederiks 1992), so any changes in the enzyme activity should be accompanied with changes in the mitochondria (Jones \& Bogitsh 1979, El-Gowhary 1993). This was confirmed by the same authors, who noticed that mitochondria appeared swollen with fewer cristae and pale matrix with the subsequent leakage of significant amounts of their enzyme content. An additional evidence of increased mitochondrial membrane permeability was shown by the increased release of mitochondrial enzyme ornithine carbamoyl transferase and isocitrate dehydrogenase into sera of human patients and experimental animals after infection with schistosomes (Rizk et al. 2000).

The mitochondrial changes could originate from the relative anoxia and irritation caused by toxic or metabolic products of adult worm and/or eggs, hence inhibition of mitochondrial oxidation (Ahmed \& Gad 1995). When limiting amounts of oxygen are present, both SDH and Krebs cycle enzyme activities are repressed (Van Hellemond \& Tielens 1994).

As concerning LDH enzyme activity the obtained results showed a significant decrease in enzyme activity after infection.

In agreement with the present results Awadalla et al. (1975) and Metwally et al. (1990) mentioned that the level of LDH was decreased in the liver tissue and increased in the serum of mice infected with S. mansoni. They attributed the decrease of enzyme activity to tissue damage caused by larvae in the infection period, led to the release of enzyme from the necrotic tissue to blood stream or due to the increased cell anoxia and irritation by toxic or metabolic products of the worm.

$\mathrm{LDH}$ is one of the glycolytic enzymes and is associated mainly with the cytoplasm (De Duve et al. 1962). Lawson and Wilson (1980) added that LDH is not a regulatory factor for glycolysis but its activity is normally re- 
TABLE IV

Effect of Citrus reticulata and Mirazid on worm burden and ova count

\begin{tabular}{|c|c|c|c|c|c|c|}
\hline \multirow[t]{2}{*}{ Parameters } & \multirow{2}{*}{$\begin{array}{c}\text { Infected } \\
(1)\end{array}$} & \multirow{2}{*}{$\begin{array}{c}\text { Infected }+ \\
\text { C. reticulata } \\
(2)\end{array}$} & \multirow{2}{*}{$\begin{array}{c}\begin{array}{c}\text { Infected + } \\
\text { Mirazid }\end{array} \\
(3)\end{array}$} & \multicolumn{2}{|c|}{ Reduction percent } & \multirow[t]{2}{*}{ ANOVA } \\
\hline & & & & C. reticulata & Mirazid & \\
\hline Worm burden & $\begin{array}{c}17.09 \pm 1.19 \\
(2,3)\end{array}$ & $\begin{array}{c}6.21 \pm 0.51 \\
(1,3)\end{array}$ & $\begin{array}{c}3.23 \pm 0.76 \\
(1,2)\end{array}$ & 63.66 & 81.10 & 0.0001 \\
\hline Ova count $\times 10^{3}$ & $\begin{array}{c}12.48 \pm 0.70 \\
(2,3)\end{array}$ & $\begin{array}{c}5.06 \pm 1.55 \\
(1,3)\end{array}$ & $\begin{array}{c}3.36 \pm 0.74 \\
(1,2)\end{array}$ & 59.45 & 73.07 & 0.0001 \\
\hline
\end{tabular}

Worm burden is expressed as means \pm S.D. of eight mice in each group; ova count is expressed as (means \pm S. D.) $\times 10^{3}$ of eight mice in each group; statistics is carried out using one way ANOVA test and the significant difference between groups is analyzed by PostHoc (SPSS Computer Program).

lated to the maximum rate of glycolysis. $\mathrm{LDH}$ inhibition revealed the aerobic-anaerobic switch induced by the developing parasite (Tielens et al.1994). Moreover, lower activity in $\mathrm{LDH}$ is in the direction of lactate oxidation which could be easily correlated to the crabtree effect of schistosomes (Tielens 1997) through which lactate is accumulated and glycogen depleted confirming inhibition of aerobic respiration and stimulation of anaerobic glycolysis through hexokinase, a rate limiting enzymes of glycolysis. The decreased enzyme activity due to the increase in anaerobic glycolysis may be attributed also to provision of energy, inhibition of Kreb's cycle, decrease NAD/NADH ratio due to inhibition of mitochondrial oxidation which favors the conversion of pyruvate to lactate, increased metabolic activity of infected liver tissues due to associated inflammation lesions, decreased hepatic blood flow, decreased utilization efficiency of other energy sources such as fat and proteins or from worms themselves which depend on anaerobic glycolysis as the main source of energy production (Ahmed \& Gad 1995).

Results of bilharzial infection on the activity of LDHisoenzymes showed that $\mathrm{LDH}_{4}$ is found to be significantly higher when compared to control, while $\mathrm{LDH}_{5}$ isoenzyme which plays the main role in the anaerobic glycolysis was significantly reduced. This is in agreement with Salah et al. (1976) who reported an increase in serum $\mathrm{LDH}_{5}$-isoenzyme in bilharzial infected patients. The reduction in the percentage contribution of $\mathrm{LDH}_{5}$ in liver may explain the false higher contribution of $\mathrm{LDH}_{1}$ which is concerned with aerobic respiration and this is not in contrast to the measured LDH enzyme activity in lactate oxidation direction previously discussed. This confirmed the opinion of Varley et al. (1980) who stated that $\mathrm{LDH}_{5}$ is increased in case of liver disease; even the total $\mathrm{LDH}$ activity is still within normal limits.

Maly and Toranelli (1993) reported that the distribution pattern of LDH activity was functionally connected with other enzyme activities involved in gluconeogenesis as pyruvate derived from lactate and alanine. In both, man and rat, more than $98 \%$ of LDH activity is represented by $\mathrm{LDH}_{5}$. This enzyme reached its maximum exactly in periportal zone of liver acinus which receives the highest oxygen supply. According to "anaerobic/aerobic" theory $\mathrm{H}$-monomere is supposed to be principally involved in the oxidation of lactate and should therefore be predomi- nant in tissues with a high oxygen supply. In contrast to this, the M-4 isoform and other isoforms rich in M subunits are geared to the reduction of pyruvate and should be predominant in tissues that are subjected to more anaerobic conditions. This led to consider the possible distribution pattern of LDH isoenzyme forms which are characterized by high values of H-subunits. They added that LDH isoenzyme shows species dependent difference in the distribution pattern where the cattle liver show $\mathrm{LDH}_{1}$, $\mathrm{LDH}_{2}$ and $\mathrm{LDH}_{3}$ activity rich in $\mathrm{H}$-subunits, while rat liver contain $\mathrm{LDH}_{5}$ only which rich in M-subunit. They explain this phenomena as the isoenzymes rich in $\mathrm{H}$-subunit could represent a safety mechanism in that they protect the liver of some species from an excessive buildup of lactate from skeletal muscle under heavy working conditions.

Concerning G-Pase enzyme activity, the present results revealed significant increase after infection with $S$. mansoni. Shaheen et al. (1989) and El-Gowhary et al. (1993) found that the enzyme activity was increased in S. mansoni infected mice liver. They attributed this increase to the proliferation and dilation of rough and smooth endoplasmic reticulum as evident by increase of ribosomes accompanied by proliferation and dilation of microsomal membranes where the enzyme is usually located and considered as microsomal marker enzyme (Van Noorden \& Frederiks 1992). Also Trela et al. (1985) attributed the increase in enzyme activity to the effect that occurs on the membrane of endoplasmic reticulum or to the elevation of cytosolic calcium that can trigger the conversion of the enzyme phosphorylase $b$ (inactive form) to phosphorylase a (active form) which degrades glycogen into glucose (Exton 1982).

Regarding AP enzyme activity, the present results showed a significant increase in enzyme activity after infection. This elevation in AP activity may be due to increased tissue catabolism resulting from increased worm and egg toxins by infection, since all the lysosomal enzymes are activated in conditions characterized by increased tissue catabolism led to enhancement of phagocytic phenomenons (Salah et al. 1976) and or due to aberration of the lysosomes, where $\mathrm{AP}$ is the lysosomal marker enzyme (Frederiks \& Marx 1988). This is in accordance with Jones and Bogitsh (1979) who found histochemically an increase in the number of mature lysosomes of the liver cells in mice after $S$. mansoni infection. These 
results confirmed those of Rodrigues (1988) who observed an important change on the lipidic constitution of the lysosomal membrane of $S$. mansoni infected mice. These changes are provoked by the catabolites excreted by immature or adult worms of S. mansoni present in the portal venous system, but El-Sharkawy et al. (1993) attributed the increase in the enzyme activity to deranged metabolic function as a result of liver cell injury.

As concerning the 5'-nucleotidase enzyme activity, the present results recorded a significant increase in its post infection. This increase in the 5'-nucleotidase enzyme activity may be due to enhancement of the active transport process through the plasma membrane where the enzyme appeared in accurate localization at bile canalicular and sinusoidal plasma membrane of liver parenchymal cells (Frederiks \& Marx 1988) and/or due to accelerated nucleic acid metabolism where the catabolism of purine and pyrimidine nucleotides starts with the action of 5'-nucleotidase (Hardonk 1968). Also, the enzyme activity may be increased due to cellular injury (Michael et al. 1979). These results were confirmed by El-Aasar et al. (1978) who demonstrated histochemically that the sinusoids of infected mice livers showed an increased 5'-nucleotidase enzyme activity.

It is concerned to study transaminases enzyme activities which showed a significant decrease after infection. El-Aasar et al. (1989) attributed the decrease of transaminase enzyme activities in mice livers to the decrease in hepatic cell population due to liver fibrosis or due to the release of the enzyme from the damaged livers into the circulation as a result of increased cell membrane permeability. The observed diminution of AST was more manifested than that of ALT denoting that, although the later is more specific for liver cells, yet it is less sensitive than AST in detecting liver cell damage (Awadalla et al. 1975). Moreover, the presence of considerably more AST in human hepatic tissue indicated that the released ALT is too diluted in the extracellular compartment to cause significant increase in the ALT activity in S. mansoni patients. Therefore, variations in the release, destruction or excretion of the two enzymes or an unknown metabolism aberration are probably important contributory mechanisms (Salah et al. 1976).

In the present study, ALP enzyme activity in infected mice showed a significant increase. Awadalla et al. (1975) and El-Aasar et al. (1989) observed an elevation in ALP activity in murine liver after $S$. mansoni infection. They attributed the increase in enzyme activity to the irritation of the liver cells by toxins or metabolic products of growing schistosomules, adult worms and eggs or due to increased loss of intracellular enzyme by diffusion through cell membranes which appears to act as a stimulus to the synthesis of more enzyme protein. Higher rates of formation would, in turn, increase the rate of diffusion and hence increase serum activity (Wilkinson 1962). Abdel-Rahman et al. (1993) mentioned a significant rise in liver ALP isoenzyme in patients having hepatosplenic schistosomiasis. Mansour et al. (1982) added that the elevation of ALP enzyme activity in S. mansoni infected human is of intestinal origin especially since $S$. mansoni is a disease which primarily affected the intestine, while this elevation is not of hepatic origin as it is observed in both patients of $S$. mansoni and hepatosplenomegaly disease.

Hunter et al. (1973) showed by histochemical studies an increase in ALP activity in experimental infection with schistosomiasis and in the late stage of human lesions by liver biopsy. Mansy et al.(1990) attributed the increase in enzyme activity to the proliferation of bile ductules and bile canaliculi as a result of schistosomiasis by ultrastructural examination of the liver specimens. This result confirmed the observation of Kaplan (1972) who suggested that the response of the liver to any form of bilary tree obstruction is to synthesize more ALP.

The present results recorded improvement levels of all enzymes under investigation after treatment of $S$. mansoni infected mice with $C$. reticulata and Mirazid. This amelioration was confirmed by a significant reduction of worm burden and ova count after treatment with both extracts. Our data is confirmed by the previous reports indicated that Mirazid is an effective drug for treatment of Fasciola hepatica, S. mansoni, and S. haematobium through worm disruption, collapse of tubercles, and reduction of worm burden as well as reduction in ova count in urine and stool (Haridy et al. 2003, Abo-Madyan et al. 2004, Massoud et al. 2004). In addition, C. reticulata contain high concentration of flavonoid, glycosides, and polymethoxylated flavones which recorded an antioxidant properties, acts as free radical scavenger and has antiinflammatory activity (Hara et al. 2004 \& Ojewole 2004). Toxic substances and free radicals elaborated by worms consume antioxidants and may affect the capacity of the liver to detoxify or naturalize the effect of the toxic endogenous and exogenous compounds (Sheweita et al. 1998). This gives an additional support that the improvement pattern in liver enzyme after treatment with $C$. reticulata resulted from its antioxidant capacity.

In conclusion, $C$. reticulata and Mirazid have no side effects on normal healthy mice and succeeded to reduce the hazardous effect of S. mansoni through improvement of liver enzymes, reduction of worm burden, and ova count. Our recommendation is to increase the treatment time of both extracts for complete eradication of worm and ova to preserve normal liver function parameters.

\section{REFERENCES}

Abdel-Rahman HM, El-Shanawani FM, Hassan MM, Salem M, El-Sahly AM 1993. Alkaline phosphatase isoenzymes abnormalities in hepatic schistosomiasis. Egypt J Bilh 15: 41-48.

Abo-Madyan AA, Morsy TA, Motawea SM 2004. Efficacy of Myrrh in the treatment of schistosomiasis (haematobium and mansoni) in Ezbet El-Bakly, Tamyia Center, El-Fayoum Governorate, Egypt. J Egypt Soc Parasitol 34: 423-446.

Ahmed SA, Gad MZ 1995. Effect of schistosomal infection and its treatment on some key enzymes of glucose metabolism in mice livers. Arzenim-Forsch 45: 1324-1328.

Awadalla HN, Sherif AF, Shafei AZ, Khalil HA, Guirgis FK 1975. Enzyme levels in homogenates of liver from mice infected with Schistosoma mansoni and from uninfected mice. Int J Parasitol 5: 27-31.

Babson AL, Babson SR 1973. Kinetic colorimetric measure- 
ment of serum lactate dehydrogenase activity. Clin Chem 19: 766-769.

Bodansky O, Schwartz MK 1963. Comparative effects of Lhistidine on the activities of 5'-nucleotidase and alkaline phosphatase. J Biol Chem 238: 3420-3427.

Bradford MM 1976. A rapid and sensitive method for the quantitation of microgram quantities of protein utilizing the principle of protein-dye binding. Anal Biochem 72: 248254.

Cheever AW, Anderson LA, 1971. Rate of destruction of Schistosoma mansoni eggs in tissues of mice. Am J Trop Med Hyg 20: 62-68.

Daugherty JW 1955. The effect of Schistosoma mansoni infections on liver function in mice. II. Further studies on intermediary metabolism. Am J Trop Med Hyg 4: 1072-1079.

De-Duve C, Wattiaux R, Baudhuin P 1962. Distribution of enzymes: subcellular fractions in animal tissues. In FF Nord, Advances in Enzymology, Interscience Publishers, NY, London, $291 \mathrm{pp}$.

Dietz AA, Lubrano T 1967. Separation and quantitation of lactic dehydrogenase isoenzymes by disc electrophoresis. Anal Biochem 20: 246-257.

El-Aasar AA, El-Merzabani MM, Zakhary NI, Farag HI, Abdeen AM, Abd El-Salam I, Mokhtar NM 1989. Biochemical and biophysical studies on schistosomal liver of mice. Egypt $J$ Bilh 11: 19-33.

El-Aasar AA, Hasanein SM, El-Bolkainy MN, El-Sebai I, ElMerzabani MM 1978. Bladder carcinogenesis in bilharzia infested Swiss albino mice. Europ J Cancer 14: 645-648.

El-Gowhary SH, Rahmy AE, El-Azzouni MZ, Nagil AI, ElMedany A 1993. Oral contraceptive pills in experimental Schistosomiasis mansoni: parasitological, biochemical, histopathological and ultrastructural studies. J Egypt Soc Parasitol 23: 609-619.

El-Sharkawy A, El-Toukhy M, Abdel-Rahman SZ, El-Kholy Z, Farag H, El-Zoghby S, Gaber N 1993. An experimental study on the effect of praziquantel and oltipraz on some lysosomal enzymes. J Trop Med Hyg 96: 28-34.

Exton JH 1982. Regulation of carbohydrate metabolism by cyclic nucleotides. In JW Kehalian JA Nathasan (eds), Cyclic Nucleotides. II. Handbook of Experimental Pharmacology, Springer-Verlag, Berlin and Heidelberg, vol. 58, p. 3-88.

Flisser A, Mclaren DJ 1989. Effect of praziquantel treatment on lung stage larvae of Schistosoma mansoni in vivo. Parasitology 98: 203-211.

FrederiksWM, Marx F 1988. A quantitative histochemical study of $5^{6}$-nucleotidase activity in rat liver using the lead salt method and polyvinyl alcohol. Histochem J 20: 207-214.

Gumucio JJ, Chiamale J 1988. Liver cell and liver function. In The Liver Biology and Pathology, Raven Press, NY, p. 931947.

Hara M, Fujinagas M, Kuboi T 2004. Radical scavenging activity and oxidative modification of citrus dehydrin. Plant Physiol Biochemistry 42: 657-662.

Hardonk MJ 1968. Distribution of 5'-nucleotidase in tissues of rat and mouse. Histochemistry 12: 1-17.

Haridy FM, El- Garhy MF, Morsy TA 2003. Efficacy of
Mirazid (Chommiphora molmol) against fascioliasis Egyptian sheep. J Egypt Soc Parasitol 33: 917-924.

Hunter S, El-Roody A, Helmi F, Mousa A 1973. Histochemical studies on hepatic schistosomiasis before and after hycanthone therapy. J Egypt Med Assoc 56: 54-68.

Ismail AA, Abou-Basha L, Abdel-Mawla AA, Fadali GA, ElZawawi T 1991. Schistosoma mansoni infection under the effect of mebendazole histopathological and histochemical studies of the liver. J Med Res Inst 12: 241-259.

Jones LG, Bogitsh BJ 1979. Further observations on ultrastructural changes in hepatocytes of mice infected with Schistosoma mansoni. Z Parasitenkd 60: 185-192.

Kabatereine NB, Kemijumbi J, Ouma JH, Sturrock RF, Butterworth AE, Madsen H, Ornbierg N, Dunne DW, Vennervald BJ 2003. Efficacy and side effects of praziquantel treatment in a highly endemic Schistosoma mansoni focus at lake Albert, Uganda. Trans R Soc Trop Med Hyg 97: 599603.

Kaplan MM 1972. Alkaline phosphatase. Gastroenterology 62: 452-468.

Kind PR, King EJ 1954. Estimation of plasma phosphatase by determination of hydrolysed phenol with amino-antipyrine. J Clin Pathol 7: 322-326.

Lawson JR, Wilson RA 1980. Metabolic changes associated with the migration of the schistosomulum of Schistosoma mansoni in the mammal host. Parasitology 81: 325-336.

Maly IP, Toranelli M 1993. Ultrathin-layer zone electrophoresis of lactate dehydrogenase isoenzymes in microdissected liver samples. Anal Biochem 214: 379-388.

Mansour MM, Farid Z, Bassily S, Salah LH, Watten RH 1982. Serum enzyme tests in hepatosplenic schistosomiasis. Trans R Soc Trop Med Hyg 76: 109-111.

Mansy SS, Abdel-Hady AA, El-Badrawy N, Akl MM, Badawy A 1990. Bile ductule proliferation in experimental hepatic schistosomiasis light and electron microscopic study. Egypt J Bilh 12: 93-102.

Manthey JA, Guthrie N 2002. Antiproliferative activities of citrus flavonoids against six human cancer cell lines. Agric Food Chem 50: 5837-5843.

Massoud AM, El-Kholy NY, El-Shennawy FA, Farag RE 2004. Study of some immune aspects in patients with fascioliasis before and after Chommiphora molmol (Mirazid) treatment. J Egypt Soc Parasitol 34: 315-332.

Metwally AA, Janku I, Kemper F, Khayyal MT, Fbeid FA, Botros SS 1990. Effect of schistosomiasis infection on the clearance of phenazone in mice. Arzenim-Forsch 40: 206209.

Michael AI, Wahab RA, Guriguis NM, El-Gazayerli IM, Hamza S 1979. Effect of Schistosoma mansoni infection in mice on hydrolytic enzyme activity of the liver. Egypt J Physiol Soc 6: $37-44$.

Nogata Y, Sekiya K, Ohta H, Kusumoto K, Ishizu T 2001. Inhibitors of platlet lipoxygenase from ponkan fruit. Phytochemistry 56: 729-732.

Ojewole JA 2004. Potentiation of anti-inflammatory effect of Amacardium occidentale (Linn.) stem-bark aqueous extract by grapefeuit. Methods Find Clin Pharmacol 26: 183-188.

Oliver L, Stirewalt MA 1952. An efficient method for the 
exposure of mice to cercariae of Schistosoma mansoni. $J$ Parasitol 39: 19-23.

Reitman S, Frankel S 1957. Colorimetric method for the determination of serum glutamic oxaloacetic and glutamic pyruvic transaminases. Am J Clin Path 28: 56-63.

Rizk M, Hafez S, Farouk H 2000. Measurment of urea cycle enzyme activities in mice under the influence of different stages of Schistosoma mansoni infection and Crucuma longa treatment. J Egypt Ger Soc Zool 32: 319-333.

Rodrigues LE 1988. Biochemistry of Schistosomiasis mansoni. VII. Lipid changes of lysosomal membranes during the initial phase of liver injury. Mem Inst Oswaldo Cruz 83: 4752.

Salah LA, Kheireldin AA, Mansour MM, Hussein F 1976. Levels of some serum enzymes in patients with schistosomiasis. Am J Trop Med Hyg 79: 270-274.

Shaheen AA, Ebeid FA, Fahim AT 1989. Effect of praziquantel on some aspects of carbohydrate metabolism in mice infected with Schistosoma mansoni. Pharmacol Res 21: 263-270.

Shelton E, Rice ME 1957. Comparison of the reduction of two tetrazolium salts with succinoxidase activity of tissue homogenates. J Nat Cancer Inst 18: 117-125.

Sheweita SA, Mangoura SA, El- Shemi AG 1998. Different levels of Schistosoma mansoni infection induced changes in drug metabolizing enzymes. J Helminthol 72: 71-77.

Silva LM, Menezes RM, De Oliveira SA, Andrade ZA 2003. Chemotherapeutic effects on larval stages of Schistosoma mansoni during infection and reinfection of mice. Rev Soc Bras Med Trop 36: 335-341.

Smithers SR, Terry RJ 1965. The infection of laboratory hosts with cercariae of Schistosoma mansoni and the recovery of worms. Parasitology 55: 695-700.

Swanson MA 1955. Glucose-6-phosphatase from liver. In Methods in Enzymology, Academic Press, Inc., NY, vol. 2, p. 541-543.

Tendler M, Pinto RM, Oliveira LA, Gebara G, Katz N 1986. Schistosoma mansoni vaccination with adult worm anti- gens. Int J Parasitol 16: 347-352.

Tielens AG 1997. Properties and function in metabolism of schistosomal hexokinase. Biochem Soc Trans 25: 127-130.

Tielens AG, Van den Heuvel JM, Van Mazijk HJ, Wilson JE, Shoemaker CB 1994. The 50-KDa glucose-6-phosphatase sensitive hexokinase of Schistosoma mansoni. J Biol Chem 269: 24736-24741.

Tkachenko JG, Kazarinova NV, Muzyehenko LM, Shurgaya AM, Pavlova OV, Safonova NG 1999. Antibiotic properties of essential oils of some plant species. Rastit Resur 35: 11-24.

Trela BA, Carlson GP, Chadwick RW, Copeland MF 1985. Comparison of in vivo and in vitro methods for assessing effects of allyl alcohol on the liver. Toxicol Lett 29: 77-84.

Van Hellemond JJ, Tielens AG 1994. Expression and functional properties of fumarate reductase. Biochem J 304: 321-331.

Van Noorden CJ, Frederiks WM 1992. Enzyme histochemical methods. In Enzyme Histochemistry, Oxford Science Publications, Amesterdam, p. 60.

Varley H, Gowenlock AH, Bell M 1980. General topics and commoner tests. In Practical Clinical biochemistry, vol. 1, 5th ed., William Heinemann Medical Books LTD, London, (White friars press), London and Tonbridge, p. 721-723.

Wang Y, Holmes E, Nicholson JK, Cloarec O, Chollet J, Tanner M, Singer BH, Utzinger J 2004. Metabolic investigations in mice infected with Schistosoma mansoni: an approach for biomarker identification. Proc Natl Acad Sci 24: 1267612681.

Wattiaux R, De Duve C 1956. Release of bound hydrolase by means of Triton X-100. Biochem J 63: 606-608.

Whitman SC, Kurowska EM, Mauthey JA, Daugherty A 2005. Nobiletin, a citrus flavonoid isolated from taugerines, selective inhibits class of actylated LDL by mouse macrophages. Atherosclorosis 178: 25-32.

Wilkinson JH 1962. The origin and fate of serum enzymes. In: An Introduction to Diagnostic Enzymology, Libbey \& Co., London, p. 259-261. 